\title{
Assessment of the anti-diabetic potential of the Cratoxylum formosum subsp. formosum extracts via carbohydrate hydrolyzing enzymes inhibitory activities
}

\author{
Kornkanok Arsakit $^{1}$, Benchaluk Thongchuai $^{1^{\mathbb{D}}}$, Sutthira Sedlak $^{2}{ }^{\mathbb{D}}$, Serm Surapinit $^{1^{*}}$ \\ ${ }^{1}$ Department of Medical Technology, School of Allied Health Sciences, University of Phayao, Phayao 56000, Thailand \\ ${ }^{2}$ Walai Rukhavej Botanical Research Institute, Mahasarakham University, Maha Sarakham 44150, Thailand
}

\section{A R T I C L E I N F O}

Article Type:

Original Article

\section{Article History:}

Received: 29 January 2020

Accepted: 6 April 2020

\section{Keywords:}

Cratoxylum

Medicinal plants

Alpha-amylase inhibitor

Hypoglycemic agents

\begin{abstract}
A B S T R A C T
Introduction: This research aims to evaluate the anti-diabetic activity of the extracts from different parts of Cratoxylum formosum subsp. formosum.

Methods: The in vitro inhibitory activities of the hexane (HEX), dichloromethane (DCM) and ethyl acetate (EtOAc) extracts from the flowers, leaves, roots and stems on pancreatic $\alpha$-amylase (pAA), Saccharomyces $\alpha$-glucosidase (SAG), rat intestinal maltase (rIM), and sucrase (rIS) were investigated.

Results: The DCM and EtOAc extracts from the flowers ( $\mathrm{IC}_{50} 5.4 \pm 1.5$ and $10.5 \pm 0.6 \mu \mathrm{g} / \mathrm{mL}$ ) displayed the similar inhibitory activities as acarbose $\left(\mathrm{IC}_{50} 7.2 \pm 0.4 \mu \mathrm{g} / \mathrm{mL}\right)$ in the pAA assay. The inhibitory activities of the DCM and EtOAc extracts from the flowers $\left(\mathrm{IC}_{50} 56.7 \pm 8.9\right.$ and $20.4 \pm 0.4 \mu \mathrm{g} / \mathrm{mL}$ ), EtOAc extract from leaves ( $\mathrm{IC}_{50} 45.0 \pm 3.5 \mu \mathrm{g} / \mathrm{mL}$ ), DCM and EtOAc extracts from roots $\left(\mathrm{IC}_{50} 35.0 \pm 6.7\right.$ and $16.7 \pm 3.6 \mu \mathrm{g} / \mathrm{mL}$ ), and EtOAc extract from stems $\left(\mathrm{IC}_{50} 31.1 \pm\right.$ $7.3 \mu \mathrm{g} / \mathrm{mL}$ ) were more potent than acarbose $\left(\mathrm{IC}_{50} 431.4 \pm 16.7 \mu \mathrm{g} / \mathrm{mL}\right)$ on SAG inhibitory assay $(P<0.05)$. In the rIM assay, DCM and EtOAc extracts from the flowers $\left(\mathrm{IC}_{50} 8.5 \pm 0.2\right.$ and $12.4 \pm 0.3 \mu \mathrm{g} / \mathrm{mL}$ ) exhibited stronger inhibitory activity than acarbose $\left(\mathrm{IC}_{50} 38.5 \pm 7.2 \mu \mathrm{g} / \mathrm{mL}\right.$ ) $(P<0.05)$. Moreover, the inhibitory activity of DCM extract from the flowers $\left(\mathrm{IC}_{50} 16.9 \pm 1.5 \mu \mathrm{g} /\right.$ $\mathrm{mL}$ ) was comparable to the acarbose ( $\mathrm{IC}_{50} 15.5 \pm 1.2 \mu \mathrm{g} / \mathrm{mL}$ ) on rIS assay.

Conclusion: The DCM and EtOAc extracts from the flowers were more active than the leaves, roots and stems in the inhibition of our defined target enzymes.
\end{abstract}

Implication for health policy/practice/research/medical education:

The flower of $C$. formosum subsp. formosum is the edible part and exert good carbohydrate hydrolyzing enzymes inhibitory activities. This part of this plant plausibly applied as a functional food to prevent and treat diabetes.

Please cite this paper as: Arsakit K, Thongchuai B, Sedlak S, Surapinit S. Assessment of the anti-diabetic potential of the Cratoxylum formosum subsp. formosum extracts via carbohydrate hydrolyzing enzymes inhibitory activities. J Herbmed Pharmacol. 2020;9(3):286-292. doi: 10.34172/jhp.2020.36.

\section{Introduction}

Diabetes mellitus is defined as a chronic disease caused by inherited and/or acquired deficiency in production of insulin by the pancreas, or by the ineffectiveness of the insulin produced. According to the World Health Organization (WHO) report, the global prevalence of diabetes in adults of age over 18 years has increased from $4.7 \%$ in 1980 to $8.5 \%$ in 2014 . Moreover, the estimated 1.6 million deaths were directly caused by diabetes as reported in $2016(1,2)$. The morbidity and mortality are not directly caused by diabetes but relatively resulted from the long-term complications in diabetes patients.
Prolonged and uncontrolled hyperglycemia is a major risk, which is associated with diabetic angiopathy, neuropathy, nephropathy, and retinopathy (3). These chronic conditions definitively lead to serious clinical complications, e.g. cardiovascular and cerebrovascular disorders, chronic renal diseases, hypertension, and cataract. Thus, the glycemic control strategy is necessary for the prevention of morbidity and mortality of diabetes (4). Diabetes, especially type 2 diabetes, can be effectively managed by diet control, physical activity changes and anti-diabetic drugs (5). Several types of medications are utilized for therapeutic purposes such as biguanides, 
sulfonylureas, thiazolidinediones, a-glucosidase inhibitors and dipeptidyl peptidase-4 (DPP-4) inhibitors. However, these modern anti-diabetic drugs still produce serious adverse effects, for example, hypoglycemia, lactic acidosis, nausea, vomiting, pancreatitis, and metabolic acidosis (6). Therefore, the discovery of anti-diabetic drugs from natural origin with minimal or without any adverse effects has been extensively investigated. Different extracts from medicinal plants have been traditionally used to control diabetes globally, which are well-considered as relatively inexpensive, less toxic and minimal adverse effects (7). Therefore, the discovery of plasma glucose-lowering agents from edible plants is the priority of our research target. The Thai edible plant Cratoxylum formosum (Jacq.) Benth. \& Hook. f. ex Dyer subsp. formosum belongs to the family Hypericaceae, which distributes mainly in North-eastern and Southern Thailand (8). The flowers, fresh shoots, and young leaves are served as vegetable in North-eastern and Southern Thai cuisines. Certain parts of C. formosum subsp. formosum have been used as Thai traditional medicines, for example, roots as a diuretic, leaves as for stomach pain relief and stems as a topical treatment for skin conditions. The major phytochemicals of the closest subspecies, C. formosum subsp. pruniflorum, are the prenylated xanthones, anthraquinones and phenolic compounds that have exhibited the topoisomerase I inhibitory, anti-cancer, anti-bacterial and cytotoxic activities (9-14). To date, there is no report on the inhibitory activity from the flowers of C. formosum subsp. formosum on the carbohydrate-hydrolyzing enzymes. Thus, the objective of this study was to assess the anti-diabetic potential of the extracts from the flower, leaf, stem and root parts of C. formosum subsp. formosum on the inhibition of porcine pancreatic $\alpha$-amylase (pAA), Saccharomyces a-glucosidase (SAG), and rat intestinal maltase (rIM) and sucrase (rIS).

\section{Materials and Methods}

Chemicals and reagents

p-Nitrophenyl-a-D-glucopyranoside (NPG), a-glucosidase from Saccharomyces cerevisiae (EC 3.2.1.20), intestinal acetone powders from rat and porcine pancreatic $\alpha$-amylase (EC 3.2.1.1) were purchased from Sigma-Aldrich, USA. Glucose LiquiColor reagent kit was purchased from HUMAN Gesellschaft für Biochemica und Diagnostica $\mathrm{mbH}$, Germany. Acarbose was purchased from Bayer Pharmaceuticals, Germany. All remaining chemicals used in this study were analytical grade.

\section{Plant Materials}

Plant samples of C. formosum subsp. formosum were collected from Roi-Et province, Thailand between October 2016 and March 2017. A plant specimen was identified and deposited at the Walai Rukhavej Botanical Research Institute, Mahasarakham University, Maha Sarakham,
Thailand (Voucher no. S. Sedlak 19-1). The leaf, flower, stem, and root parts of the plant were cleaned then dried in a hot-air oven at $50^{\circ} \mathrm{C}$ for 48 hours before the extraction process.

\section{Extraction procedure}

Ground plant samples (400 g) were extracted by Soxhlet extractor using methanol as an extracting solvent for 6 hours. Methanolic extracts from each part were concentrated under the vacuum condition by rotary evaporator. The methanol extracts were suspended in deionized water and successfully partitioned with hexane (HEX), dichloromethane (DCM), and ethyl acetate (EtOAc), respectively. The organic solvents were removed to yield HEX, DCM, and EtOAc extracts. The extracts were stored at $-20^{\circ} \mathrm{C}$ until use. The crude extracts were dissolved in $50 \% \mathrm{DMSO} / \mathrm{H}_{2} \mathrm{O}$ before the enzyme inhibitory assays.

Porcine pAA inhibitory assay

The inhibitory assay of the crude extract was evaluated by the amyloclastic method. The assay was modified from the previous report to a 96-well microtiter plate format $(15,16)$. The stock solution of porcine pancreatic aamylase was prepared by dissolving $50 \mathrm{mg}$ of the enzyme in $10 \mathrm{~mL}$ of buffer $(10 \mathrm{mM}$ phosphate saline buffer $\mathrm{pH}$ $6.9,10 \mathrm{mM} \mathrm{CaCl}_{2}$, and $0.04 \% \mathrm{NaN}_{3}$ ) to yield a $65 \mathrm{U} /$ $\mathrm{mL}$ of the enzyme. The working enzyme solution was diluted from a stock solution to a concentration of $0.1 \mathrm{U} /$ $\mathrm{mL}$. The reaction mixture consisted of $40 \mu \mathrm{L}$ of working enzyme solution, $50 \mu \mathrm{L}$ of $1.25 \mathrm{mg} / \mathrm{mL}$ of amylose and $10 \mu \mathrm{L}$ of crude extract was dissolved in $50 \% \mathrm{DMSO} / \mathrm{H} 2 \mathrm{O}$ and incubated for 10 minutes at $37^{\circ} \mathrm{C}$. The reaction was terminated by the addition of the $100 \mu \mathrm{L}$ of iodine reagent $\left(0.2 \mathrm{mM} \mathrm{KOI}_{3}, 4.2 \mathrm{mM} \mathrm{KI}\right.$ and $\left.1.6 \mathrm{mM} \mathrm{HCl}\right)$ and further incubated for 3 minutes. The starch-iodine complex was determined by measurement of absorbance at $655 \mathrm{~nm}$. The inhibition percentage (IP) values of crude extracts were calculated according to the equation;

$I P=100 \times\left[\frac{A_{\text {blank }}-A_{\text {test }}}{A_{\text {blank }}}\right]$

All extracts were screened at the final concentration of $100 \mu \mathrm{g} / \mathrm{mL}$ in triplicate. The IP values from screening assay were expressed as mean \pm SD. The IP was plotted against the crude extract concentration to obtain the amount of extract necessary to inhibit porcine pAA by $50 \%\left(\mathrm{IC}_{50}\right)$. The data were obtained from 5 independent experiments and expressed as mean \pm SEM, each conducted in triplicate.

\section{SAG inhibitory assay}

The a-glucosidase inhibitory assay was performed in a 96-well microtiter plate format (17). The stock enzyme solution of a-glucosidase from S. cerevisiae was 
prepared by dissolving enzyme in a buffer solution $(0.5 \mathrm{M}$ phosphate buffer $\mathrm{pH} 6.5,0.1 \%$ bovine serum albumin and $0.01 \% \mathrm{NaN}_{3}$ ). The working enzyme solution was diluted from a stock solution to a concentration of $3 \mathrm{U} /$ $\mathrm{mL}$. The reaction mixture consisted of $20 \mu \mathrm{L}$ of working enzyme solution, $70 \mu \mathrm{L}$ of buffer solution and $10 \mu \mathrm{L}$ of crude extract solution was pre-incubated for 5 minutes at $37^{\circ} \mathrm{C}$. The reaction mixture contained $10 \mu \mathrm{L} 50 \% \mathrm{DMSO} /$ $\mathrm{H}_{2} \mathrm{O}$ instead of a crude extract solution that was set as the blank. The reaction was started by adding $50 \mu \mathrm{L}$ of $20 \mathrm{mM}$ NPG and further incubated for 20 minutes. The reaction was terminated by adding $50 \mu \mathrm{L}$ of $1 \mathrm{M} \mathrm{Na}_{2} \mathrm{CO}_{3}$. The absorbance was measured at $405 \mathrm{~nm}$ against a buffer blank. All extracts were screened at the final concentration of $100 \mu \mathrm{g} / \mathrm{mL}$ in triplicate. The IP values from screening assay were expressed as mean $\pm \mathrm{SD}$. The IP and $\mathrm{IC}_{50}$ values of crude extracts were calculated and plotted in the same manner of the porcine pAA inhibitory assay. The data were obtained from 5 independent experiments and expressed as mean \pm SEM, each conducted in triplicate.

rIM and rIS inhibitory assay

The rIM and rIS inhibitory assays were performed in a 96-well microtiter plate format (18). The $0.1 \mathrm{~g}$ of rat intestinal acetone powder was dissolved in $10 \mathrm{~mL}$ of 0.1 phosphate saline buffer $\mathrm{pH} 6.8$ at $4^{\circ} \mathrm{C}$ overnight. The enzyme suspension was centrifuged $\left(12000 \mathrm{~g}\right.$ at $4^{\circ} \mathrm{C}$ for 15 minutes) and the supernatant was kept for further enzymatic activity determination. The $30 \mu \mathrm{L}$ of enzyme solution was incubated with $10 \mu \mathrm{L}$ of $100 \mathrm{mM}$ maltose or sucrose as substrates at $37^{\circ} \mathrm{C}$ for 10 minutes. The reaction was terminated by heating in a hot bath at $100^{\circ} \mathrm{C}$ for 3 minutes and cooled down in tab water. The amount of glucose released from maltose and sucrose was assayed by the Glucose LiquiColor reagent kit. The maltase unit was defined as an amount of enzyme to convert $1 \mu \mathrm{M}$ of maltose to $2 \mu \mathrm{M}$ of glucose in 1 minute under the assay condition. The sucrase unit was defined as an amount of enzyme to convert $1 \mu \mathrm{M}$ of sucrose to $1 \mu \mathrm{M}$ of glucose in 1 minute under the assay condition. The enzyme solution was diluted to the concentration of $100 \mathrm{U} / \mathrm{mL}$ maltase and sucrose. The reaction mixture consisted of $10 \mu \mathrm{L}$ of enzyme solution, $10 \mu \mathrm{L}$ of crude extract dissolved in $50 \%$ DMSO/H2O and $30 \mu \mathrm{L}$ of a substrate $(10 \mathrm{mM}$ maltose or $30 \mathrm{mM}$ sucrose) and incubated for 10 minutes at $37^{\circ} \mathrm{C}$. The reaction mixture containing $10 \mu \mathrm{L} 50 \%$ DMSO/ $\mathrm{H}_{2} \mathrm{O}$ instead of crude extract solution was set as blank. The reaction was terminated by incubation in a hot water bath for 5 minutes and cooled down in tap water before the determination of liberated glucose. The IP values of crude extracts were calculated according to the equation;

$I P=100 \times\left[\frac{\text { Glucose }_{\text {blank }}-\text { Glucose }_{\text {test }}}{\text { Glucose }_{\text {blank }}}\right]$

All extracts were screened at the final concentration of
$100 \mu \mathrm{g} / \mathrm{mL}$ in triplicate. The IP values from screening assay were expressed as mean \pm SD. The IP was plotted against the crude extract concentration to obtain the amount of extract necessary to rIM and rIS by $50 \%\left(\mathrm{IC}_{50}\right)$. The data were obtained from 5 independent experiments and expressed as mean \pm SEM, each conducted in triplicate.

\section{Statistical analysis}

One-way ANOVA was used to test for overall differences. Significant ANOVA was followed by Duncan's multiple comparisons for consideration of pair-wised differences between treatment groups. A $P$ value of less than 0.05 was considered statistically significant.

\section{Results}

pAA inhibitory activities

According to the screening assay, the DCM and EtOAc extracts from the flowers, DCM extract from the roots, and CDM extract from the stems exhibited strong pAA inhibitory activities (Figure 1A). These extracts were obtained for further determination for the inhibitory activity. The saccharolytic inhibition of the DCM ( $\mathrm{IC}_{50}$ $5.4 \pm 1.5 \mu \mathrm{g} / \mathrm{mL})$ and EtOAc $\left(\mathrm{IC}_{50} 10.5 \pm 0.6 \mu \mathrm{g} / \mathrm{mL}\right)$ extracts from the flowers were not significantly different with acarbose $\left(\mathrm{IC}_{50} 7.2 \pm 0.4 \mu \mathrm{g} / \mathrm{mL}\right.$ ) (Table 1). All extracts from the leaf part were inactive. The DCM extracts from the roots $\left(\mathrm{IC}_{50} 37.3 \pm 1.1 \mu \mathrm{g} / \mathrm{mL}\right)$ and stems $\left(\mathrm{IC}_{50} 76.7 \pm\right.$ $12.1 \mu \mathrm{g} / \mathrm{mL}$ ) were less potent than acarbose. By contrast, the EtOAc extracts from both parts were inactive.

\section{SAG inhibitory activities}

The result of SAG inhibitory activities demonstrated that DCM and EtOAc extracts from the flowers, EtOAc extract from the leaves, DCM and EtOAc from the roots, and EtOAc from the stems had significant inhibitory activities (Figure 1B). The EtOAc extract $\left(\mathrm{IC}_{50} 20.4 \pm 0.4 \mu \mathrm{g} / \mathrm{mL}\right.$ ) was more active than the DCM extract $\left(\mathrm{IC}_{50} 56.7 \pm 8.9 \mu \mathrm{g} /\right.$ $\mathrm{mL}$ ) and acarbose $\left(\mathrm{IC}_{50} 431.4 \pm 16.7 \mu \mathrm{g} / \mathrm{mL}\right)$, the referent compound $(P<0.05)$ (Table 1$)$. The EtOAc extract $\left(\mathrm{IC}_{50}\right.$ $45.0 \pm 3.5 \mu \mathrm{g} / \mathrm{mL}$ ) from the leaves was also more potent than acarbose $(P<0.05)$, whereas the DCM extract was not active at the screening concentration $(100 \mu \mathrm{g} / \mathrm{mL})$. The EtOAc extract $\left(\mathrm{IC}_{50} 16.7 \pm 3.5 \mu \mathrm{g} / \mathrm{mL}\right)$ from the roots was more potent than the DCM $\left(\mathrm{IC}_{50} 35.0 \pm 6.7 \mu \mathrm{g} / \mathrm{mL}\right)$ and acarbose $(P<0.05)$. The inhibitory activity of the EtOAc extract $\left(\mathrm{IC}_{50} 31.1 \pm 7.3 \mu \mathrm{g} / \mathrm{mL}\right)$ form the stems was more potent than acarbose $(P<0.05)$, while the DCM extract was inactive.

rIM and rIS inhibitory activities

As the results from intestinal maltase inhibitory assay, DCM and EtOAc extracts from the flowers, DCM and EtOAc extracts from the leaves, DCM and EtOAc extracts from the roots, and DCM and EtOAc extracts from the stem were subjected to evaluation for the rIM inhibitory 

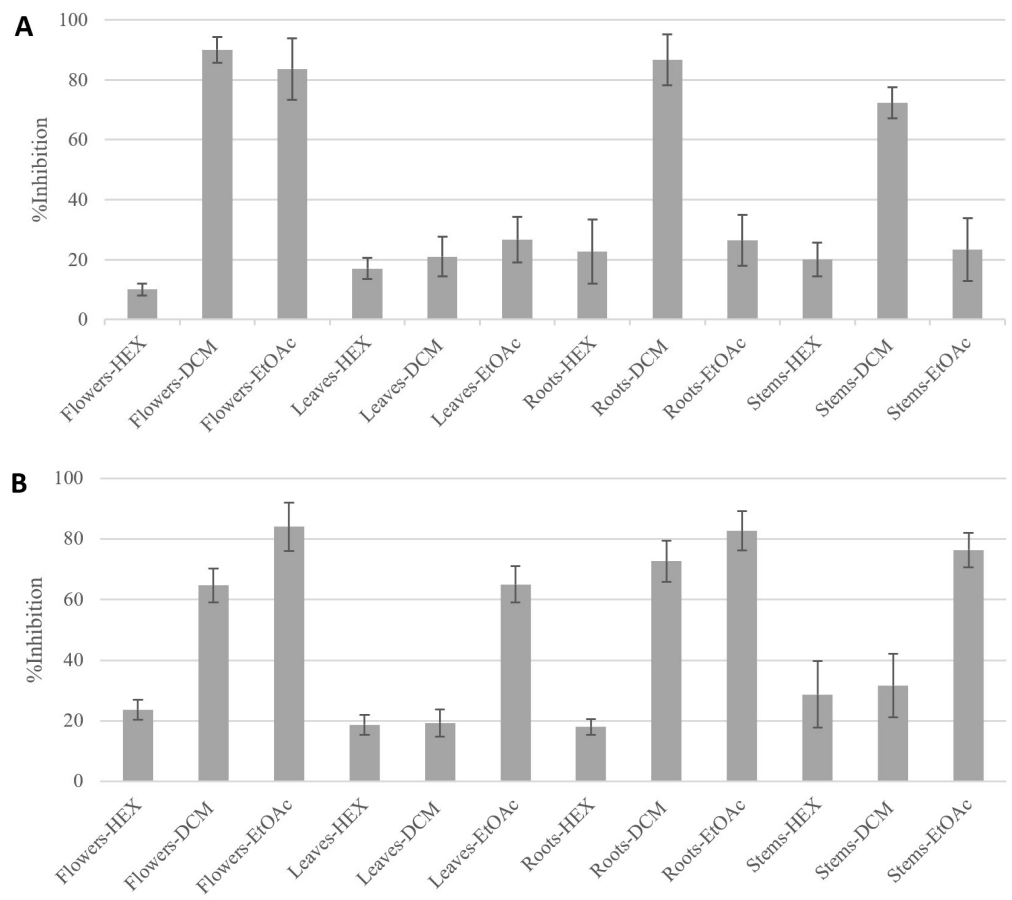

Figure 1. The inhibition percentage of the extracts from different parts of $C$. formosum subsp. formosum on the porcine pancreatic $\alpha$-amylase (pAA) (A), and Saccharomyces $\alpha$-glucosidase (SAG) (B) at $100 \mu \mathrm{g} / \mathrm{mL}$ (Mean \pm SD). HEX, hexane; DCM, dichloromethane; EtOAc, ethyl acetate.

activity (Figure $2 \mathrm{~A})$. The DCM $\left(\mathrm{IC}_{50} 8.5 \pm 0.2 \mu \mathrm{g} / \mathrm{mL}\right)$ and EtOAc $\left(\mathrm{IC}_{50} 12.4 \pm 0.3 \mu \mathrm{g} / \mathrm{mL}\right)$ extracts from the flowers were more potent than acarbose $\left(\mathrm{IC}_{50} 38.5 \pm 7.2 \mu \mathrm{g} / \mathrm{mL}\right)$ $(P<0.05)$ (Table 1). The DCM extract from the leaves $\left(\mathrm{IC}_{50} 76.8 \pm 2.3 \mu \mathrm{g} / \mathrm{mL}\right)$ was less potent than the EtOAc extract $\left(\mathrm{IC}_{50} 45 \pm 2.7 \mu \mathrm{g} / \mathrm{mL}\right)$ and acarbose $(P<0.05)$. The DCM and EtOAc extracts from the roots were comparable to acarbose in the maltase inhibitory capability. The inhibitory activity of DCM extract $\left(\mathrm{IC}_{50} 67.40 \pm 2.2 \mu \mathrm{g} /\right.$ $\mathrm{mL})$ from the stems was less active than the EtOAc one $\left(\mathrm{IC}_{50} 40.9 \pm 1.5 \mu \mathrm{g} / \mathrm{mL}\right)$ and acarbose $(P<0.05)$.

The DCM and EtOAc extracts from the flowers, EtOAc extract from the leaves, EtOAc extract from the roots, and EtOAc extract from the stems were obtained for the rIS inhibitory activity assay (Figure 2B). The effect of CDM extract $\left(\mathrm{IC}_{50} 16.9 \pm 1.5 \mu \mathrm{g} / \mathrm{mL}\right)$ from the flowers was the

Table 1. The inhibitory activities of the extracts from different parts of $C$. formosum subsp. formosum on the pAA, SAG, rIM and rIS (Mean \pm SEM; $\mu g / m L$ )

\begin{tabular}{|c|c|c|c|c|c|}
\hline Parts & Extract & pAA & SAG & rIM & rIS \\
\hline \multirow{3}{*}{ Flowers } & HEX & NA & NA & NA & NA \\
\hline & $\mathrm{DCM}$ & $5.4 \pm 1.5$ & $56.7 \pm 8.9^{*}$ & $8.5 \pm 0.2^{*}$ & $16.9 \pm 1.5$ \\
\hline & EtOAc & $10.5 \pm 0.6$ & $20.4 \pm 0.4^{*}$ & $12.4 \pm 0.3^{*}$ & $39.9 \pm 3.1^{*}$ \\
\hline \multirow{3}{*}{ Leaves } & HEX & NA & NA & NA & NA \\
\hline & DCM & NA & NA & $76.8 \pm 2.3^{*}$ & NA \\
\hline & EtOAc & NA & $45.0 \pm 3.5^{*}$ & $45 \pm 2.7$ & $61.8 \pm 1.5^{*}$ \\
\hline \multirow{3}{*}{ Roots } & HEX & NA & NA & NA & NA \\
\hline & $\mathrm{DCM}$ & $37.3 \pm 1.1^{*}$ & $35.0 \pm 6.7^{*}$ & $54.9 \pm 4.9 *$ & NA \\
\hline & EtOAc & NA & $16.7 \pm 3.6^{*}$ & $37.4 \pm 2.0$ & $60.0 \pm 2.5^{*}$ \\
\hline \multirow{3}{*}{ Stems } & HEX & NA & NA & NA & NA \\
\hline & DCM & $76.7 \pm 12.1^{*}$ & NA & $67.4 \pm 2.2^{*}$ & NA \\
\hline & EtOAc & NA & $31.1 \pm 7.3^{*}$ & $40.9 \pm 1.5$ & $75.7 \pm 4.1^{*}$ \\
\hline Acarbose & & $7.2 \pm 0.4$ & $431.4 \pm 16.7$ & $38.5 \pm 7.2$ & $15.5 \pm 1.2$ \\
\hline
\end{tabular}

$* P<0.05$ as compared to acarbose

NA not active at the screening concentration of $100 \mu \mathrm{g} / \mathrm{mL}$.

pAA, pancreatic $\alpha$-amylase; SAG, Saccharomyces $\alpha$-glucosidase; rIM, rat intestinal maltase; rIS, rat intestinal sucrase; HEX, hexane; DCM, dichloromethane; EtOAc, ethyl acetate. 




B

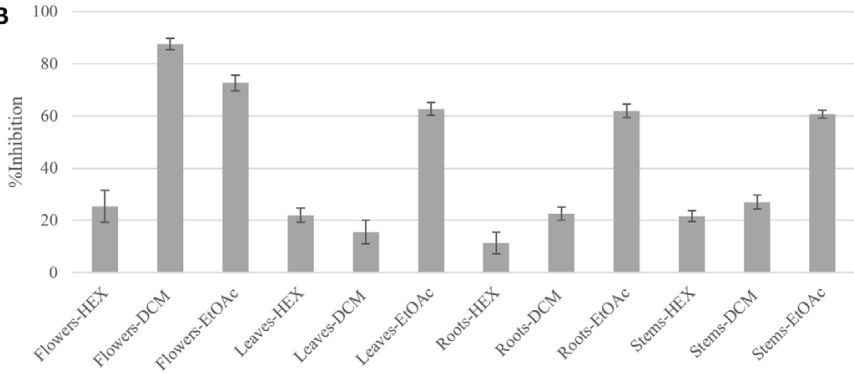

Figure 2. The inhibition percentage of the extracts from different parts of $C$. formosum subsp. formosum on rat intestinal maltase (rIM) (A), and rat intestinal sucrase (rIS) (B) at $100 \mu \mathrm{g} / \mathrm{mL}($ Mean $\pm S D)$. HEX, hexane; DCM, dichloromethane; EtOAc, ethyl acetate.

same as the acarbose $\left(\mathrm{IC}_{50} 15.5 \pm 1.2 \mu \mathrm{g} / \mathrm{mL}\right)$. By contrast, the EtOAc extract from the flowers $\left(\mathrm{IC}_{50} 39.9 \pm 3.1 \mu \mathrm{g} /\right.$ $\mathrm{mL})$ was less potent than acarbose $(P<0.05)$ (Table 1$)$. The HEX and DCM extracts from the leaves were inactive under the assay condition. The EtOAc extract $\left(\mathrm{IC}_{50} 61.8\right.$ $\pm 1.5 \mu \mathrm{g} / \mathrm{mL}$ ) from the leaves was less active than acarbose $(P<0.05)$. The HEX and DCM extracts from the roots and stems were inactive. The EtOAc extracts from the leaves $\left(\mathrm{IC}_{50} 60.0 \pm 2.5 \mu \mathrm{g} / \mathrm{mL}\right)$ and stems $\left(\mathrm{IC}_{50} 75.7 \pm 4.1 \mu \mathrm{g} / \mathrm{mL}\right)$ were less active than acarbose $(P<0.05)$.

\section{Discussion}

Certain a-glucosidase inhibitors (acarbose, miglitol, voglibose) are one group of the diabetic drugs for the patient's glycemic control, which competitively inhibit carbohydrate-hydrolyzing enzymes to delay digestion of carbohydrates and absorption of the monosaccharides $(19,20)$. Human pAA is the first intestinal enzyme that catalyses the hydrolysis of 1,4-glucan linkage in the ingested starch to yield maltose, maltotriose, several of $\alpha-(1,6)$ and $\alpha-(1,4)$ oligoglycans, and a small amount of glucose. The 3D structural comparison by X-ray diffraction demonstrated that human pAA had a high degree of structural identity to the porcine enzyme (21). Moreover, the enzyme kinetic characteristics and enzymeinhibitor interaction (acarbose) between human and porcine enzymes were not significantly different (22). Thus, the porcine pAA was reasonable to use this enzyme as the experimental target in this study. These results led to the conclusion that the flowers of $C$. formosum subsp. formosum possessed the potent pAA inhibitory activity as compared to acarbose.

Saccharomyces cerevisiae a-glucosidase is a 1,4-a-glycosidic bond-specific hydrolase widely used as a target for the searching of anti-diabetic agents from natural origins (23). The results revealed that the EtOAc from the roots and flowers were the most active extracts among different extracts from this plant. HEX extracts from all parts were completely inactive under the assay concentration $(100 \mu \mathrm{g} / \mathrm{mL})$. Maltose is the disaccharide that is mainly released from the hydrolysis of starch catalysed by intestinal $\alpha$-amylase. Maltase is the membrane-bound enzyme located in the intestinal brush border, and is the last enzyme to cleave maltose to release two molecules of glucose before intestinal absorption. Sucrase is another membrane-bound enzyme which hydrolyses ingested sucrose to glucose and fructose (24). The rIM and rIS were acceptable models for the humanliked maltase and sucrase inhibitory assays (25). The results demonstrated that the CDM extracts from the flowers were the most active extracts of this plant in the rIM and rIS inhibitory assays.

The investigation of porcine pAA, SAG, rIM and rIS inhibitory activities demonstrated that the flower part of C. formosum subsp. formosum displayed the strongest anti-diabetic potential. The DCM and EtOAc extracts exhibited the inhibitory activities while the HEX was completely inactive. This result indicated that the nonpolar constituents dissolved in hexane from the flowers were not the active ingredients. There were no phytochemical and biological activities reported from the flowers of this plant. The polar extract, EtOAc extract, from the leaf part of C. formosum subsp. formosum showed potent SAG, rIM and rIS inhibitory activities. Recently, the phenolic compounds from the ethanolic extract of $C$. formosum subsp. formosum leaves exhibited the in vitro protective effects against $\mathrm{H}_{2} \mathrm{O}_{2}$-induced cell death, and antioxidant activities (26). The DCM root extract exhibited moderate 
pAA, rIM, and rIS inhibitory activities. Besides, the EtOAc extract from the roots showed strong $\alpha$-glucosidase inhibitory activity. The phytochemical constituents have not been reported from the roots of this subspecies. Several prenylated xanthones, anthraquinones, flavonols, and phenolic compounds have been isolated and identified from the roots of $C$. formosum $(27,28)$. Moreover, certain caged and prenylated xanthones were isolated from the roots of $C$. cochinchinense $(29,30)$. The polar part of the stems, EtOAc extract, showed strong SAG, and potent rIM and rIS inhibitory activities. The chemical constituents from the stems of $C$. formosum ssp. pruniflorum and $C$. cochinchinense were prenylated xanthone, benzophenone glycosides and bisanthraquinone (31-33).

\section{Conclusion}

The inhibitory effects of the different parts of the $C$. formosum subsp. formosum demonstrated the antidiabetes potential. The DCM and EtOAc extracts from the flowers and roots showed the significant saccharolytic inhibitory activities via the pAA, SAG, rIM, and rIS inhibitory activities. The DCM extracts from the leaves and stems also showed potent rIM inhibitory activity, whereas the EtOAc extracts from these parts exhibited the significant SAG, rIM, and rIS inhibitory activities. The obtained results indicated that these active extracts possibly inhibited the carbohydrate-hydrolyzing enzyme through the interferences of catalytic activity. However, the exact mechanisms of enzymatic inhibition were not revealed by the defined assay protocol. Thus, extensive enzyme kinetic studies are needed to clarify the inhibitory mechanisms. Although the in vitro study indicates the possibility of this plant for the prevention and treatment of diabetes, the in vivo study is extensively needed to assess the therapeutic effectiveness and toxicological effects for therapeutic purposes.

\section{Authors' contribution}

SS collected and identified the plant specimens. KA and BT tested the enzyme inhibition and analysed the data. SS conducted the project and wrote the paper. All authors read and confirmed the publication of the paper.

\section{Conflict of interests}

The authors declare no conflict of interest.

\section{Ethical considerations}

Ethical issues (including plagiarism, misconduct, data fabrication, falsification, double publication or submission, redundancy) have been completely observed by the authors. The authors affirm that no animal and human subjects were involved in this research.

\section{Funding/Support}

The authors are grateful to the University of Phayao for financial support (RD60086).

\section{References}

1. Diagnosis and classification of diabetes mellitus. Diabetes Care. 2011;34 Suppl 1:S62-9. doi: 10.2337/dc11-S062.

2. Glycemic targets: standards of medical care in diabetes-2018. Diabetes Care. 2018;41(Suppl 1):S55-s64. doi: 10.2337/ dc18-S006.

3. Forbes JM, Cooper ME. Mechanisms of diabetic complications. Physiol Rev. 2013;93(1):137-88. doi: 10.1152/physrev.00045.2011.

4. Martinez LC, Sherling D, Holley A. The screening and prevention of diabetes mellitus. Prim Care. 2019;46(1):4152. doi: 10.1016/j.pop.2018.10.006.

5. Zimmet P. Preventing diabetic complications: a primary care perspective. Diabetes Res Clin Pract. 2009;84(2):10716. doi: 10.1016/j.diabres.2009.01.016.

6. Alhadramy MS. Diabetes and oral therapies: a review of oral therapies for diabetes mellitus. J Taibah Univ Med Sci. 2016;11(4):317-29. doi: 10.1016/j.jtumed.2016.02.001.

7. Bindu J, Narendhirakannan RT. Role of medicinal plants in the management of diabetes mellitus: a review. 3 Biotech. 2019;9(1):4. doi: 10.1007/s13205-018-1528-0.

8. Maisuthisakul P, Pongsawatmanit R, Gordon MH. Characterization of the phytochemicals and antioxidant properties of extracts from Teaw (Cratoxylum formosum Dyer). Food Chem. 2007;100(4):1620-9. doi: 10.1016/j. foodchem.2005.12.044.

9. Nonpunya A, Sethabouppha B, Rufini S, Weerapreeyakul N. Cratoxylum formosum ssp. pruniflorum activates the TRAIL death receptor complex and inhibits topoisomerase I. S Afr J Bot. 2018;114:150-62. doi: 10.1016/j.sajb.2017.11.003.

10. Boonnak N, Karalai C, Chantrapromma S, Ponglimanont C, Fun HK, Kanjana-Opas A, et al. Bioactive prenylated xanthones and anthraquinones from Cratoxylum formosum ssp. pruniflorum. Tetrahedron. 2006;62(37):8850-9. doi: 10.1016/j.tet.2006.06.003.

11. Kaewpiboon C, Boonnak N, Yawut N, Kaowinn S, Chung YH. Caged-xanthone from Cratoxylum formosum ssp. pruniflorum inhibits malignant cancer phenotypes in multidrug-resistant human A549 lung cancer cells through down-regulation of NF-kappaB. Bioorg Med Chem. 2019;27(12):2368-75. doi: 10.1016/j.bmc.2018.12.042.

12. Xiong J, Liu XH, Bui VB, Hong ZL, Wang LJ, Zhao Y, et al. Phenolic constituents from the leaves of Cratoxylum formosum ssp. pruniflorum. Fitoterapia. 2014;94:114-9. doi: 10.1016/j.fitote.2014.02.002.

13. Kaewpiboon C, Boonnak N, Kaowinn S, Chung YH. Formoxanthone C, isolated from Cratoxylum formosum ssp. pruniflorum, reverses anticancer drug resistance by inducing both apoptosis and autophagy in human A549 lung cancer cells. Bioorg Med Chem Lett. 2018;28(4):820-5. doi: $\quad$ 10.1016/j.bmcl.2017.07.066.

14. Nonpunya A, Weerapreeyakul N, Barusrux S. Cratoxylum formosum (Jack) Dyer ssp. pruniflorum (Kurz) Gogel. (Hóng yá mù) extract induces apoptosis in human hepatocellular carcinoma HepG2 cells through caspase-dependent pathways. Chin Med. 2014;9(1):12. doi: 10.1186/17498546-9-12.

15. Okutan L, Kongstad KT, Jäger AK, Staerk D. High- 
resolution alpha-amylase assay combined with highperformance liquid chromatography-solid-phase extraction-nuclear magnetic resonance spectroscopy for expedited identification of alpha-amylase inhibitors: proof of concept and alpha-amylase inhibitor in cinnamon. J Agric Food Chem. 2014;62(47):11465-71. doi: 10.1021/ jf5047283.

16. Cole MR, Rose I, Chung YJ, Eggleston G. A structured approach to target starch solubilisation and hydrolysis for the sugarcane industry. Food Chem. 2015;166:165-72. doi: 10.1016/j.foodchem.2014.05.151.

17. Li W, Wei K, Fu H, Koike K. Structure and absolute configuration of clerodane diterpene glycosides and a rearranged cadinane sesquiterpene glycoside from the stems of Tinospora sinensis. J Nat Prod. 2007;70(12):19716. doi: 10.1021/np070367i.

18. Morikawa T, Chaipech S, Matsuda H, Hamao M, Umeda Y, Sato H, et al. Antidiabetogenic oligostilbenoids and 3-ethyl4-phenyl-3,4-dihydroisocoumarins from the bark of Shorea roxburghii. Bioorg Med Chem. 2012;20(2):832-40. doi: 10.1016/j.bmc.2011.11.067.

19. Marín-Peñalver JJ, Martín-Timón I, Sevillano-Collantes C, Del Cañizo-Gómez FJ. Update on the treatment of type 2 diabetes mellitus. World J Diabetes. 2016;7(17):354-95. doi: 10.4239/wjd.v7.i17.354.

20. Reusch JE, Manson JE. Management of type 2 diabetes in 2017: getting to goal. JAMA. 2017;317(10):1015-6. doi: 10.1001/jama.2017.0241.

21. Brayer GD, Luo Y, Withers SG. The structure of human pancreatic alpha-amylase at $1.8 \mathrm{~A}$ resolution and comparisons with related enzymes. Protein Sci. 1995;4(9):1730-42. doi: 10.1002/pro.5560040908.

22. Ferey-Roux G, Perrier J, Forest E, Marchis-Mouren G, Puigserver A, Santimone M. The human pancreatic alpha-amylase isoforms: isolation, structural studies and kinetics of inhibition by acarbose. Biochim Biophys Acta. 1998;1388(1):10-20. doi: 10.1016/s0167-4838(98)00147-2.

23. Choi CW, Choi YH, Cha MR, Yoo DS, Kim YS, Yon GH, et al. Yeast alpha-glucosidase inhibition by isoflavones from plants of Leguminosae as an in vitro alternative to acarbose. J Agric Food Chem. 2010;58(18):9988-93. doi: 10.1021/ jf101926j.

24. Eggermont E. The hydrolysis of the naturally occurring alpha-glucosides by the human intestinal mucosa. Eur J Biochem. 1969;9(4):483-7. doi: 10.1111/j.1432-1033.1969. tb00634.x.

25. Pyner A, Nyambe-Silavwe H, Williamson G. Inhibition of human and rat sucrase and maltase activities to assess antiglycemic potential: optimization of the assay using acarbose and polyphenols. J Agric Food Chem. 2017;65(39):8643-51. doi: 10.1021/acs.jafc.7b03678.

26. Yingngam $B$, Monschein $M$, Brantner A. Ultrasoundassisted extraction of phenolic compounds from Cratoxylum formosum ssp. formosum leaves using central composite design and evaluation of its protective ability against H2O2-induced cell death. Asian Pac J Trop Med. 2014;7S1:S497-505. doi: 10.1016/s1995-7645(14)60281-9.

27. Inuma $\mathrm{M}$, Tosa $\mathrm{H}$, Ito $\mathrm{T}$, Tanaka $\mathrm{T}$, Madulid DA. Two xanthones from roots of Cratoxylum formosanum. Phytochemistry. 1996;42(4):1195-8. doi: 10.1016/00319422(96)00111-2.

28. Boonsri S, Karalai C, Ponglimanont C, Kanjana-opas A, Chantrapromma K. Antibacterial and cytotoxic xanthones from the roots of Cratoxylum formosum. Phytochemistry. 2006;67(7):723-7. doi: 10.1016/j.phytochem.2006.01.007.

29. Laphookhieo S, Syers JK, Kiattansakul R, Chantrapromma $\mathrm{K}$. Cytotoxic and antimalarial prenylated xanthones from Cratoxylum cochinchinense. Chem Pharm Bull (Tokyo). 2006;54(5):745-7. doi: 10.1248/cpb.54.745.

30. Mahabusarakam W, Nuangnaowarat W, Taylor WC. Xanthone derivatives from Cratoxylum cochinchinense roots. Phytochemistry. 2006;67(5):470-4. doi: 10.1016/j. phytochem.2005.10.008.

31. Duan YH, Dai Y, Wang GH, Zhang X, Chen HF, Chen JB, et al. Bioactive xanthones from the stems of Cratoxylum formosum ssp. pruniflorum. J Nat Prod. 2010;73(7):1283-7. doi: 10.1021/np1001797.

32. Duan YH, Dai Y, Wang GH, Chen HF, Gao H, Chen JB, et al. Xanthone and benzophenone glycosides from the stems of Cratoxylum formosum ssp. pruniflorum. Chem Pharm Bull (Tokyo). 2011;59(2):231-4. doi: 10.1248/cpb.59.231.

33. Rattanaburi S, Daus M, Watanapokasin R, Mahabusarakam W. A new bisanthraquinone and cytotoxic xanthones from Cratoxylum cochinchinense. Nat Prod Res. 2014;28(9):60610. doi: 10.1080/14786419.2014.886212. 